\title{
MODEL SISTEM PERTANIAN PADI ORGANIK: PEMBERDAYAAN PETANI SKALA KECIL (STUDI KASUS DESA SUNDAKERTA, KECAMATAN SUKAHENING, KABUPATEN TASIKMALAYA)
}

\author{
Mahra Arari Heryanto* ${ }^{1}$, Kuswarini Kusno ${ }^{1}$, Gema Wibawa Mukti ${ }^{1}$, Tetep Ginanjar ${ }^{2}$ \\ ${ }^{1}$ Departemen Sosial Ekonomi Pertanian, Fakultas Pertanian Universitas Padjadjaran \\ ${ }^{2}$ Kelompok Riset Sistem Rantai Pasok dan Logistik Pertanian, Universitas Padjadjaran \\ Email: mahra.arari@unpad.ac.id
}

\begin{abstract}
ABSTRAK
Kebergantungan petani padi terhadap program pemerintah telah berlangsung lama sejak dijalankan Revolusi Hijau digulirkan. Dibalik prestasi peningkatan produksi pangan, terdapat kerusakankerusakan yang saat ini disadari atau tidak oleh petani dari aspek sosial dan lingkungan. Sistem pertanian organik muncul sebagai inovasi dan solusi bagi persoalan sosial dan lingkungan. Keberdayaan petani yang terdiri dari sosial, ekonomi dan lingkungan digambarkan dalam suatu struktur model sistem pertanian organik menggunakan pendekatan berpikir sistem (system thinking). Studi kasus ini dilakukan pada kelompok tani padi organik yang usahanya berskala kecil di Desa Sundakerta, Kecamatan Sukahening, Kabupaten Tasikmalaya. Kelembagaan sosial yang diterjemahkan dalam konsep modal sosial menjadi akslerator dalam proses peningkatan keberdayaan petani. Aksi bersama (collective action) sebagai "buah" dari "pohon" modal sosial (kepercayaan, aturan dan jejaring sosial) memegang peranan penting dalam menggerakan peningkatan keberdayaan petani dari aspek sosial, eknomi, dan lingkungan.
\end{abstract}

Kata kunci: modal sosial, aksi kolektif, berpikir sistem, kelembagaan sosial, pemberdayaan

\begin{abstract}
Farmer dependency toward governemnt policy have been existed in a long period since Green Revolution started. Behind the food incresed achievement, there was some failure that realized or not by farmers socially and environmentally. Organic farming system currently emerge as solution and innovation for social and environemntal failure. Farmer empowerment which consist of social, economics and environemental aspect are illustrated in a model structure of organic farming system using system thinking approach. These case study was held in a farmer group with small scale organic farming at Sundakerta Village, Kecamatan Sukahening, Kabupaten Tasikmalaya. Social institution which is translated into social capital opperationally, pay role as engine or accelerator in order to increase the powerment level of farmer. Collective action as "fruit" of social capital "tree" (trust, norm and obligation, and social networking) play an important role in movement of farmer empowerment in social, economics and environement aspects.
\end{abstract}

Keywords: social capital, collective action, system thinking, social institution, empowerment

\section{PENDAHULUAN}

Penggunaan input produksi kimia yang intensif pada usahatani padi merupakan upaya percepatan peningkatan produksi pangan yang pada era orde baru dilakukan secara sistematis dan makanistik. Sadono (2008) mengungkapkan bahwa tekanan alih teknologi untuk meningkatkan produktivitas dan produksi saat itu mengakibatkan petani menjadi tergantung, tidak mandiri dan kelembagaan lokal menjadi kurang berfungsi atau bahkan hilang. Tingkat keberdayaan petani dalam konteks ini menjadi rendah dan sangat bergantung kepada program pemerintah yang bersifat top down.
Tingkat keberdayaan petani yang diukur oleh Mutmainah (2015) dari kemampuan dan kemandirian petani dalam berwirausaha disadari atau tidak, telah mengalami pengikisan melalui tekanan alih teknologi yang masif. Kemandirian petani yang diartikan kemampuan petani dalam mengarahkan usahataniya yang diyakini paling tinggi manfaatnya menurut Sumodiningrat (1999), telah berkurang sejalan dengan besarnya tekanan "metode baru berorientasi produksi" yang didifusikan kepada petani.

Upaya pembangunan yang berorientasi produksi (production centered development) 
dilakukan dengan mengeksploitasi dan memanipulasi sumber daya alam untuk menghasilkan produksi bagi masyarakat konsumen berskala massal. Dampaknya adalah kebijakan pembangunan sangat berpihak kepada konsumen dan meminggirkan peran produsen, yakni para petani yang ada di perdesaan (Nasdian, 2014). Kegiatan pembangunan (eksploitasi sumberdaya alam) yang sejatinya bertujuan untuk meningkatkan kesejahteraan masyarakat dikatakan oleh Ife dan Tesoriero (2008) telah banyak mengakibatkan kerusakan alam yang serius dan memorak porandakan sisitem-sistem sosial, ekonomi, dan budaya masyarakat Indonesia. Alih-alih meningkatkan kesejahteraan petani, pembangunan pertanian yang "top down" mengakibatkan depresiasi keberdayaan petani yang mengurangi kemampuan dan kemandirian petani dalam berwirausahatani.

Fenomena di atas oleh kaum "green" disebut sebagai ekonomi konvensional yang hanya mementingkan nilai-nilai ekonomi daripada nilai sosial dan ekologis. Pembangunan yang berorientasi produksi pada faktanya berfungsi memperkuat orde ekonomi tetapi bersifat merusak secara sosial dan ekologis. Orientasi nilai ekonomi produksi mendorong petani untuk menggunakan input luar berbiaya rendah menyebar dengan cepat di kalangan produsen dan mengakibatkan kebergantungan yang tinggi. Akibatnya keberdayaan petani menjadi hilang, petani sangat bergantung terhadap keberadaan sarana produksi yang berasal dari luar lingkungannya (Ife dan Tesoriero, 2008; Tawaf et al, 2011). Merujuk kepada nilai-nilai ekonomi, produksi pangan dapat ditingkatkan dengan asupan teknologi yang efisien, tetapi dalam jangka panjang persoalan kerusakan sosial dan ekologis akan menghambat "keberlanjutan" ekonomi.

Solusi dari persoalan di atas adalah sistem pertanian organik. Beban (2008) membuktikan bahwa pertanian organik yang ramah lingkungan membuat petani berdaya dalam arti mampu menyediakan sarana produksi (input) pertaniannya sendiri yang selama ini merupakan biaya produksi yang harus dibayar oleh petani kepada penyedia sarana produksi di luar lingkungannya. Kristiansen, et al (2006) menyatakan bahwa pertanian organik merupakan jawaban atas persoalan "keberlanjutan" yang harus adaptif terhadap faktor usahatani, sosial, geografis dan iklim lokal.
Tulisan ini bermaksud untuk menguraikan bagaimana sistem pertanian organik mampu meningkatkan keberdayaan petani yang selama ini telah terdepresiasi oleh pertanian yang mengandalkan input dari luar (pupuk dan pestisida kimia). Kelembagaan sosial dalam kegiatan pemberdayaan sistem pertanian organik memiliki peranan yang penting. Pernyataan Nasdian (2014) mengenai pentingnya peran kelembagaan sosial dalam suatu aktivitas pemberdayaan mendasari konsep modal sosial yang digambarkan dalam suatu struktur pertanian usahatani padi yang dibandingkan antara sistem usahatani padi organik dan konvensional (input kimia). Penelitian dilakukan di kelompok tani yang mengusahakan padi organik di Kecamatan Sukahening, Kabupaten Tasikmalaya.

\section{METODE}

Metode yang digunakan adalah desain kualitatif yang bersifat eksploratori. Diperlukan pemahaman yang holistik dan komprehensif dalam sistem pertanian organik dilihat dari aspek kelembagaan sosial. Pemahaman tersebut sejalan dengan Maxwell (1996) yang mengungkapkan bahwa penelitian kualitatif memiliki kekuatan pemahaman terhadap suatu persoalan, mampu mengidentifikasi fenomena dan pengaruh yang tidak terduga dan memahami proses dari suatu kejadian dan aksi.

Kelengkapan informasi untuk menjawab pertanyaan penelitian adalah pertimbangan yang paling utama dalam menentukan sumber informasi dalam penelitian kualitatif. Sumber informasi / informan dalam penelitian kualitatif bersifat panel, yaitu orang yang secara unik memiliki kemampuan informatif karena keahliannya dalam kejadian tertentu (Maxwell, 1996). Petugas Internal Control System (ICS), petani dan kelompok tani adalah sumber informasi (informan) yang ditentukan berdasarkan kemampuan informatif dan keahliannya sebagai aktor dan pelaku dalam sistem pertanian padi organik di Desa Sundakerta, Kecamatan Sukahening, Kabupaten Tasikmalaya.

Adapun kelompok tani yang dimaksud adalah kelompok tani yang telah menerapkan sistem pertanian padi organik. Pengalaman kelompok tani organik antara sebelum menerapkan sistem pertanian organik dan setelah menerapkan sistem pertanian organik adalah akumulasi informasi yang sangat penting dalam penelitian ini. 
Sebagai suatu model, Forrester (1975) menyebutkan sumber utama data dalam pembuatan struktur kelembagaan sosial sistem pertanian organik adalah data kualitatif. Data yang dimaksud dapat berupa basis data numerik, basis data dokumen/tertulis maupun basis data mental berupa keputusan.

Data-data tersebut diperoleh dengan menggunakan teknik wawancara secara individu dan kelompok yang divalidasi secara triangulasi di antara informan dan menggunakan struktur model yang dibangun dengan pendekatan cara berpikir sistem (system thinking).

Pendekatan System Thinking merupakan pendekatan yang mengenali hubungan saling bergantung (interdependent) dan berkaitan (interrelated) berbagai unsur-dalam suatu struktur yang memiliki tujuan tertentu. Pendekatan berpikir sistem menganut paradigma bahwa dinamika dimunculkan oleh hasil kerja simultan suatu struktur (unsur-unsur pembentuk yang saling bergantung) (Senge, 2006; Sterman, 2000; Tasrif, 2004).

Unsur-unsur yang dimaksud dalam struktur terdiri dari unsur modal sosial, pengetahuan petani, dan usahatani padi. Unsur-unsur tersebut menurut Sterman (2000) saling bergantung yang membentuk suatu hubungan sebab akibat umpan balik (feedback loop) dan merupakan proses yang berlanjut (on going process). Umpan balik tersebut kemudian bekerja secara simultan dengan kandungan berbagai aktivitas inidividu sehingga membentuk kompleksitas tinggi. Umpan balik atau feedback dalam struktur merupakan kendali bagi peneliti sekaligus validasi dalam pembentukan perilaku sistem.

Validasi menurut Maxwell (1996) adalah tahapan yang tidak dapat dihilangkan dalam suatu penelitian untuk menghasilkan kesimpulan yang sahih. Validasi merupakan proses membangun kepercayaan dari model peneltian yang dilakukan (Sterman, 2000). Validasi dalam penelitian ini menggunakan teknik triangulasi antara dunia nyata (antar informan) dengan feedback dalam struktur model. Umpan balik (feedback) mejadi indikator kunci bagi peneliti untuk mengenali aliran sebab akibat yang logis dalam membaca fenomena atau empiris (evidence), apakah model yang dibangun telah dapat menggambarkan persoalan atau fenomena yang terjadi.

\section{HASIL DAN PEMBAHASAN}

Pemahaman yang holistik terhadap proses dari ketersalinghubungan dalam sistem pertanian padi, baik organik maupun konvensional menjadi fokus dalam hasil dan pembahasan yang dijelaskan dalam suatu diagram sebab-akibat dengan pendekatan system thinking. Adapun kelembagaan sosial dalam tulisan ini merujuk kepada ungkapan Coleman (1988) mengenai konsep modal sosial yang digambarkan dalam struktur sebagai relasi antar aktor atau dalam kelompok. Perubahan relasi antar individu atau kelompok menentukan aksi dari para aktor yang terlibat dalam sistem pertanian organik.

Proses adopsi inovasi dalam pembahasan ini bersandar kepada tesis yang dibuat oleh Randers (1973) yang menyebutkan bahwa akumulasi informasi menjadi pengetahuan kolektif yang berakumulasi akan mempercepat penerimaan terhadap penemuan baru. Tjitropranoto (2005) melengkapi pengetahuan, keterampilan dan sikap sebagai penentu adopsi teknologi pertanian.

Para petani padi organik di Desa Sundakerta, Kec. Sukahening sebagian besar merupakan petani skala kecil dengan penguasaan lahan rata-rata kurang dari 0,25 hektar per petani. Jumlah anggota kelompok di Desa Sundakerta yang mengusahakan padi organik adalah 16 orang yang keseluruhannya tergabung ke dalam Gapoktan Simpatik berjarak 20-an kilometer dari domisili para petani.

Tabel 1. Penguasaan Lahan per Petani Padi Organik Desa Sundakerta, Kecamatan Sukahening, Kab. Tasikmalaya

\begin{tabular}{cc}
\hline Deskripsi & Luas (Hektar) \\
\hline Rata-rata & 0,225 \\
Maksimal & 0,643 \\
Minimal & 0,081 \\
Median & 0,203 \\
\hline
\end{tabular}

\section{Adopsi Inovasi Sistem Pertanian} Organik: Menguntungkan atau Merugikan Petani Skala Kecil? Sistem pertanian organik suatu hal yang baru bagi para petani padi yang selama ini mengusahakan tanaman padinya secara konvensional (menggunakan input kimia). Sejak era Revolusi Hijau, Heryanto et al (2016) mengatakan bahwa sistem pertanian padi di Indonesia diarahkan kepada penggunaan pupuk dan pestisida kimia yang berlangsung selama empat dekade. 


\begin{tabular}{|c|c|}
\hline $\begin{array}{l}\text { Tujuan } \\
\text { Memahami secara } \\
\text { komprehensif dan } \\
\text { holistik sistem } \\
\text { pertanian organik } \\
\text { dalam hubungan sosio- } \\
\text { teknis }\end{array}$ & $\begin{array}{l}\text { Konteks } \\
\text { Konseptual } \\
\text { Kelembagaan } \\
\text { sosial: modal sosial } \\
\text { Pengembangan } \\
\text { Masyarakat } \\
\text { Adopsi Inovasi }\end{array}$ \\
\hline \multicolumn{2}{|c|}{$\begin{array}{l}\text { Pertanyaan Penelitian } \\
\text { Bagaimana sistem pertanian organik mampu } \\
\text { meningkatkan keberdayaan petani? } \\
\text { Faktor penentu keberhasilan sistem } \\
\text { pertanian organik yag memberdayakan } \\
\text { petani? }\end{array}$} \\
\hline $\begin{array}{l}\text { Metode } \\
\text { Wawancara mendalam } \\
\text { dengan petani dan } \\
\text { kelompok } \\
\text { Diskusi kelompok } \\
\text { terfokus dengan } \\
\text { kelompok tani } \\
\text { Analisis dokumen } \\
\text { Analisis sebab-akibat } \\
\text { sistem kelembagaan } \\
\text { sosial dengan System } \\
\text { Thinking }\end{array}$ & $\begin{array}{l}\text { Validasi } \\
\text { Triangulasi antar } \\
\text { aktor (informan), } \\
\text { diagram sebab-akibat, } \\
\text { dan teori } \\
\text { Mencari eviden } \\
\text { (empiris) yang berbeda } \\
\text { atau kasus negatif } \\
\text { Memperhatikan } \\
\text { feedback dari kondisi } \\
\text { yang paling ekstrim } \\
\text { dalam struktur sistem }\end{array}$ \\
\hline
\end{tabular}

Gambar 3. Kerangka Penelitian (diadaptasi dari Maxwell, 1996)

Inovasi sebagai penemuan baru hendaknya memberikan manfaat kepada para pelaku yang mengadopsinya baik secara ekonomi, sosial, maupun lingkungan. Meminjam istilah Tjiptropranoto (2005) bahwa diseminasi yang berorientasi untuk pengembangan kapasitas diri petani lah yang paling baik dalam proses adopsi inovasi memperkuat pentingnya umpan balik dalam proses adopsi inovasi. Umpan balik yang dimaksud berupa respon yang diberikan secara sosial, ekonomi dan lingkungan. Apabila umpan balik bernilai positif, dapat dikatakan teknologi baru (pertanian organik) sebagai inovasi.

Merujuk Tjiptropranoto di atas, sistem pertanian organik sebagaimana diilustrasikan dalam Gambar 2 secara umum (secara detil dapat dilihat pada Gambar 3 dan Gambar 4), lebih dapat mengembangkan kapasitas diri petani dibandingkan dengan sistem pertanian konvensional. Pengetahuan petani pada sistem pertanian organik lebih berkembang dengan adanya usaha peternakan yang menambah pengetahuan petani dari aspek integrasi tanaman dan ternak (umpan balik R4 Gambar 4). Penggunaan limbah peternakan untuk penyubur tanaman dan penggunaan limbah pertanian utuk pakan ternak memberikan benefit dari aspek pengetahuan dan wawasan petani secara sosial.

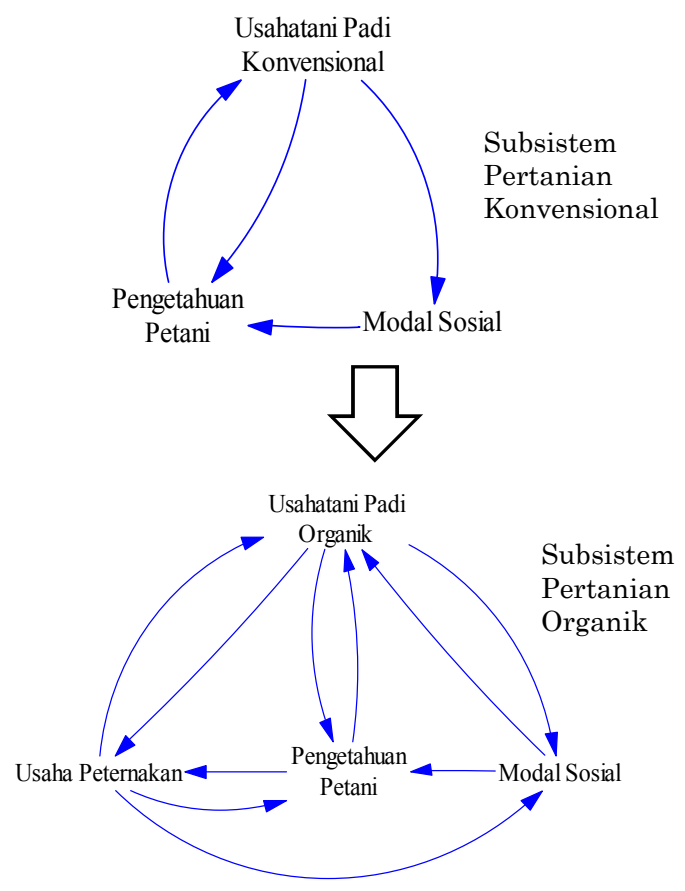

Gambar 4. Perbandingan Subsistem Usahatani Padi Konvensional dan Organik

Begitu pula secara ekonomi, diversifikasi usaha peternakan yang merupakan eksternalitas bagi sistem pertanian organik memberikan efisiensi yang tinggi terhadap asupan produksi sektor pertanian. Hal yang sama berlaku bagi usaha peternakan, efisiensi diperoleh dari penggunaan pakan yang berasal dari limbah pertanian (umpan balik R4 Gambar 4). Selain itu, dari usaha peternakan itu sendiri petani memperoleh penghasilan tahunan (penggemukan) dan harian (bagi petani yang mengusahakan susu ternak) (umpan balik R3 Gambar 4). Bagi petani skala kecil, efisiensi biaya input produksi pertanian menjadi sangat berarti untuk membantu meningkatkan pendapatannya. Begitu juga diversifikasi pendapatan dari usaha peternakan yang dapat berperan sebagai tabungan atau investasi keluarga terutama pada kondisi yang mendesak.

Efisiensi produksi juga terjadi pada tahap persiapan lahan. Struktur tanah lahan sawah yang diusahakan setelah melalui masa konversi (4 kali musim tanam) menjadi lebih remah dan mudah untuk dibajak, sehingga biaya persiapan lahan mennjadi lebih rendah dibandingkan dengan konvensional. 
Ditinjau dari aspek budidaya, produktivitas padi organik relatif sama dibandingkan dengan padi konvensional dengan kisaran 5-7 ton per hektar. Petani menuturkan bahwa penurunan produktivitas pernah terjadi walaupun tidak semua, selama masa konversi dari konvensional ke organik pada empat kali musim tanam awal padi organik. Kondisi ini wajar dialami oleh banyak pertanian organik di seluruh dunia berdasarkan hasil penelitian yang ditulis oleh Kristiansen, et al., (2006).

Diskursus mengenai pertanian organik dan konvensional secara global dapat diukur dari produktivitas, ekonomi, efisensi penggunaan sumber daya, dampak lingkungan dan faktor sosial terkait dengan peternakan (Kristiansen, et al, 2006). Pada skala mikro pertanian organik dengan menggunakan konsep yang dikembangkan oleh Tjiptopranoto cukup mampu menigkatkan kapasitas diri petani baik secara sosial maupun ekonomi. Bahkan dari sisi penambahan pengetahuan, sistem kolektif kelompok dengan kelembagaan yang baik pada kelompok pertanian organik memiliki kecepatan arus pengetahuan lebih besar dibandingkan dengan kelompok petani konvensional (Gambar 3 dan Gambar 4). Analisis tersebut diperoleh dari kalkulasi jumlah umpan balik/feedback loop pada unsur penambahan pengetahuan: feedback yang bekerja pada pengetahuan petani konvensional 70 feedback loop; sementara itu pengetahuan petani organik mencapai 487 feedback loop.

Sejalan dengan apa yang diungkap oleh Kristiansen, et al., (2006), pada tataran global sistem pertanian organik di Desa Sundakerta, Kec. Sukahening secara ekonomi (komersial), sosial maupun lingkungan memiliki positif. Kearifan terhadap binatang di sekitar lahan dan dampak yang minimal terhadap lingkungan menjadi catatan tersendiri bagi para petani di Desa Sundakerta untuk tetap meneruskan sistem pertanian padi organik.

\section{Kelembagaan Sosial dalam Sistem}

Pertanian Organik. Pemahaman tentang perubahan kelembagaan sangat penting dalam kajian suatu inovasi, tidak terkecuali sistem pertanian organik yang dapat dikatagorikan sebagai inovasi. Kelembagaan-kelembagaan sosial yang dimaksud pada tingkat komunitas di Indonesia dapat mengembangkan dan mengoptimalkan perubahan kelembagaan dalam bentuk modal sosial (Alfiasari et al, 2009; M. Karaulova et al, 2016).
Perdebatan mengenai konsep modal sosial telah terjadi sejak lama antara sosiolog Bourdieu, James Coleman dan Robert Putnam. Ketiga definisi modal sosial yang dibangun oleh para sosiologi memiliki kesamaan yang merujuk kepada proses sosial yang dielaborasi oleh Winter (2000) modal sosial sebagai sumberdaya untuk aksi bersama (collective action), terdiri dari norma dan sanksi, saling percaya yang secara operasional terdapat dalam jejaring sosial.

Merujuk kepada definis di atas, modal sosial dalam struktur model diidentifikasi ke dalam tiga unsur utama yang diutarakan Winter. Secara operasional pada tataran kelompok tani dapat diidentifikasi beberapa aktivitas yang termasuk ke dalam modal sosial (Tabel 2).

Tabel 2. Unsur Modal Sosial dalam Kelompok Tani

\begin{tabular}{ll}
\hline Unsur Modal Sosial & \multicolumn{1}{c}{$\begin{array}{c}\text { Operasional pada } \\
\text { Kelompok Tani }\end{array}$} \\
\hline a) Kepercayaan & $\begin{array}{l}\text { Kepercayaan terhadap } \\
\text { kelompok tani* }\end{array}$ \\
b) Norma dan aturan & $\begin{array}{l}\text { Aturan kelompok*, } \\
\text { Sanksi Kelompok* }\end{array}$ \\
c) Jaringan Sosial & $\begin{array}{l}\text { Pertemuan rutin*, } \\
\text { Diskusi antar petani* }\end{array}$ \\
\hline * unsur yang terdapat dalam struktur sistem \\
pertanian konvensional (Gambar 3) dan sistem \\
pertanian organik (Gambar 4)
\end{tabular}

Ketiga unsur tersebut dalam sistem pertanian padi baik organik maupun konvensional saling berinteraksi membentuk suatu struktur. Kesatuan struktur tersebut menghasilkan perilaku sistem yang apabila dideskripsikan merupakan kombinasi dari keputusan para aktor dan artefak teknis yang digunakan.

\section{a) Kepercayaan}

Kepercayaan terhadap kelompok tani merupakan dasar utama bagi ke-16 anggota kelompok untuk terus tergabung dalam kelompok tani yang diberi nama kelompok tani Mekar Jaya. Para anggota sampai saat ini merasakan suatu kebersamaan dalam kelompok tani terutama pada saat menjalankan sistem pertanian organik.

Kepercayaan terhadap kelompok tani disebabkan oleh tiga unsur, yaitu manfaat dari padi organik, penggunaan input produksi dan sanksi kelompok (Gambar 4). Manfaat dari padi organik bersumber dari keberhasilan usahatani padi organik itu sendiri dan 
eksternalitas yang berasal dari usaha peternakan. Semakin besar manfaat yang diperoleh dari padi organik akan menambah tingkat kepercayaan terhadap kelompok tani.

Kepercayaan terhadap kelompok tani juga disebabkan oleh penggunaan input produksi. Dalam sistem pertanian organik, penggunaan pupuk dan pestisida kimia adalah suatu pelanggaran yang tidak bisa ditolerir. Walaupun dari sisi perubahan perilaku petani hal tersebut tidak mudah, tetapi dengan banyaknya manfaat (benefit) yang diterima oleh petani yang mulai beralih ke sistem organik (Heryanto, et al, 2016) akan mempercepat proses transformasi dari penggunaan input kimia ke input organik. Sanksi kelompok pada kasus ini memiliki peran untuk mengendalikan perilaku petani anggota untuk selalu konsisten dalam penggunaan input organik. Penerapan sanksi atas pelanggaran tersebut menumbuhkan kepercayaan terhadap kelompok bahwa kelompok tani Mekar Jaya benar-benar sebagai kelompok tani sistem pertanian organik. b) Norma dan aturan

Aturan dalam sistem pertanian organik adalah regulasi kelompok yang berperan sebagai rambu-rambu dalam menjalankan usahatani padi organik. Setiap pelanggaran dari rambu-rambu pertanian organik akan dikenakan sanksi sebagai konsekuensi dari suatu aturan agar kepercayaan terhadap kelompok dapat tetap terjaga (Gambar 3 dan Gambar 4).

Aturan dan sanksi kelompok merupakan bagian dari keberadaan modal sosial atau secara konseptual oleh Coleman (1988) dan Winter (2000) disebutkan sebagai norma. Aturan dan sanksi dalam kelompok disepakati oleh para anggota kelompok, dalam waktu tiga tahun terakhir terdapat beberapa anggota (1-2 orang) yang pada akhirnya tidak diakui sebagai anggota kelompok tani. Ketegasan ini juga didorong oleh pengawasan yang dilakukan oleh ICS dari Gapoktan Simpatik dalam rangka menjaga kualitas beras organik dengan predikat sertifikat organik internasional.

Kondisi tersebut agak berbeda dengan kelompok sistem pertanian padi konvensional, aturan yang berlaku relatif lebih longgar dibandingkan dengan kelompok pertanian organik. Aturan yang ada hanya sebatas pada sistem pertanian rendah input yang telah didiseminasikan selama kurang lebih 4 dekade. Kecepatan inovasi yang cenderung lambat pada sistem pertanian padi konvensional (Heryanto dan Supyandi, 2016) berdampak kepada rendahnya "eksistensi" aturan di tingkat petani. Transformasi dari Revolusi Hijau menjadi Revolusi Hijau Lestari yang memasukan unsur spesifik lokal (Zaini, 2009), dalam penerapannya belum cukup kuat untuk menumbuhkan aturan-aturan yang dikemas dalam bentuk teknologi untuk meningkatkan produktivitas padi. Bahkan dalam beberapa kasus, produktivitas padi organik dapat mengungguli produktivitas padi konvensional.

Konsep Revolusi Hijau yang begitu kuat pada petani padi konvensional telah "meninabobo"-kan kreatifitas petani karena ketergantungan yang besar kepada ketersediaan pupuk kimia murah yang disubsidi dan keandalan pestisida kimia yang banyak tersedia dan mudah diakses. Akibatnya (berdasarkan penuturan petani) pada saat terjadi persoalan serangan hama petani cukup membeli pestisida ke toko saprodi tanpaperlu berkomunikasi dengan sesama petani lainnya, terkecuali terjadi serangan hama yang luar biasa.

c) Jaringan sosial

Pelemahan aturan dan norma dari sisi perkembangan teknologi secara tidak langsung berimbas kepada jaringan sosial petani padi konvensional yang dari luar tampak kokoh (karena interaksi di luar usahatani padi), ternyata rapuh bila dilihat dari kegiatan yang bersifat kolektif. Anggota kelompok merasa bahwa sistem kolektif terbangun dengan baik pada saat usahatani padinya beralih ke sistem pertanian organik. Sebelumnya para petani lebih bersifat individualistis. Intensitas pertemuan kelompok dilakukan hanya beberapa kali saja dalam setahun, yakni pada saat akan pencatatan dan realisasi penyaluran pupuk bersubsidi. Pada saat terjadi serangan hama mereka lebih memilih mendatangi toko saprodi untuk mencari penawarnya daripada berdiskusi dengan petani lainnya.

Pola interaksi antar petani berubah drastis sejak kelompok memutuskan untuk mengadopsi sistem pertanian organik yang menurut Morgera, et al (2012) praktek usahatani organik disebut sebagai sistem manajemen produksi yang menjaga kesehatan agro-ekosistem termasuk keanekaragaman biologi, aktivitas daur biologi, dan biologi tanah. Petani dituntut tidak hanya memperhatikan peningkatan produksi padi, tetapi juga dituntut untuk menjaga kualitas 
lingkungan agar tetap terjaga dan tidak mengganggu aktivitas biologis lingkungan yang ada di dalam dan sekitar sawah. Tuntutan yang tinggi dalam sistem pertanian organik kemudian mendorong petani untuk mengubah perilaku dalam berproduksi agar dapat memenuhi standar sistem pertanian organik.

Keterbatasan pengetahun petani tentang pertanian organik memaksa mereka untuk banyak belajar dari ICS Gapoktan Simpatik dan berdiskusi antar petani. Pemanfaatan sumberdaya lokal seperti pupuk dan pestisida alami membuat antar anggota lebih sering bertemu baik secara formal maupun informal untuk memperoleh informasi apa yang boleh dan apa yang tidak tidak boleh dilakukan dalam pertanian organik.

Para petani merasakan bahwa arus pertambahan pengetahuan petani setelah beralih ke sistem pertanian organik mengalami peningkatan. Akumulasi pengetahuan petani organik bertambah dengan cepat dibandingkan petani konvensional yang arus pengetahuannya relatif kecil karena hanya bergantung pasif kepada sumber pengetahuan yang salurannya hanya sedikit. Berbeda dengan petani organik yang dituntut untuk kreatif memanfaatkan sumberdaya lokal yang di sekitar desa. Petani organik selain memperoleh pengetahuan dari sumber pengetahuan juga secara aktif mencari dan mengeksplorasi berbagai peluang demi terwujudnya sistem pertanian organik yang menghasilkan dan ramah terhadap lingkungan.

Aktivitas kolektif yang dilakukan oleh petani menjadi lebih hidup dengan penerapan sistem pertanian organik. Kepercayaan terhadap kelompok, aturan kelompok, dan interaksi/pertemuan antar anggota secara bersama-sama mempercepat aliran penambahan modal sosial sehingga akumulasi yang terbentuk menjadi lebih besar. Untuk meyakinkan hal tersebut, dengan menggunakan kalkulasi jumlah feedback loop pada penambahan modal sosial sistem pertanian organik diperoleh sebanyak 368 feedback loop, sementara itu pada sistem pertanian konvensional hanya 55 feedback loop saja. Artinya kompleksitas pada sistem pertanian lebih tinggi sehingga peluang aliran yang menambah modal sosial pada petani padi organik lebih besar dibandingkan aliran yang menambah modal sosial petani padi konvensional

Kolektifitas dapat diwujudkan dari intensitas kerjasama dan interaksi dalam pelaksanaan usahatani. Koutsou, et al (2014) mengilustrasikan modal sosial sebagai suatu pohon, dimana kepercayaan berperan sebagai akar dan pondasi, jaringan (network) sebagai daun dan batang, yang kemudian akan dihasilkan suatu aksi bersama (collective action) sebagai buah dari modal sosial.

\section{Modal Sosial: Akslerator}

Pemberdayaan Petani Skala Kecil. Apa yang dikatakan Koutsou di atas tampaknya tidak berlebihan dan dirasakan oleh petani organik di Desa Sundakerta Kec. Sukahening. Kebersamaan yang dirasakan oleh petani organik menjadikan mereka secara sosial menjadi lebih solid dari sebelumnya.

Terdapat tiga faktor utama yang menentukan keberhasilan pertanian organik dalam memberdayakan petaninya: sumberdaya individu, kekuatan kelompok tani, dan kebijakan serta dukungan lembaga. Pemberdayaan masyarakat diartikan sebagai masyarakat yang berhasil mencapai kehidupannya yang lebih baik (Beban, 2008). Kehidupan yang lebih baik disini bagi para petani organik kelompok Mekarjaya sejalan dengan Morgera et al (2012) dapat dilihat secara sosial, ekonomi dan lingkungan. a) Manfaat Sosial Pertanian Organik Dilihat dari aspek sosial, penyerapan tenaga kerja dan penguatan komunitas atau kelompok sangat dirasakan oleh para anggota kelompok dan masyarakat desa. Pemanfaatan sumber daya lokal untuk maksimalisasi produksi seperti penyediaan pupuk dan pestisida organik yang dilakukan secara bersama-sama tanpa harus menunggu bantuan pupuk subsidi yang selama ini sering menjadi kendala dalam realisasinya. Petani menuturkan, sejak menggunakan pupuk organik, para petani merasa terbebas dari belenggu ketersediaan pupuk kimia, kapanpun selama ada kemauan mereka mampu menyediakan pupuk dan pestisida secara mandiri. Morgera, et al (2012) juga menggarisbawahi manajemen lingkungan antar sesama petani dalam menjaga integritas sumber air dan tanah menumbuhkan solidaritas antar petani dalam satu kawasan pertanian organik.

Negosiasi pemasaran gabah organik yang didekasikan untuk Gapoktan Simpatik menumbuhkan rasa kebersamaan dan kekeluargaan antar anggota. Menjelang panen pembeli (Gapoktan Simpatik) melakukan negosiasi kepada para anggota kelompok 
mengenai volume, kualitas dan harga gabah yang dibeli oleh Gapoktan Simpatik.

Dari keseluruhan manfaat sosial yang dirasakan, keberadaan modal sosial dalam kelembagaan pertanian organik mampu mempercepat proses peningkatan keberdayaan petani menuju kehidupannya yang lebih baik. Tanpa kepercayaan, aturan dan norma, dan jaringan sosial yang baik, proses memperoleh kehidupan yang lebih petani akan banyak menemui hambatan.

b) Manfaat Ekonomi Pertanian Organik

Pertanian organik adalah sektor dengan pertumbuhan pangan tertinggi di dunia dengan nilai pertumbuhan antara 20-25 persen selama 10 tahun terakhir. Kondisi tersebut merupakan peluang dan tantangan yang dapat dimanfaatkan oleh para petani padi organik untuk meningkatkan produksinya.

Perkembangan isu kesehatan telah mendorong para konsumen untuk mengonsumsi pangan sehat yang terbebas dari residu kimia. (Morgera et al, 2012)

Secara mikro, hal tersebut merupakan peluang sekaligus tantangan untuk memperbesar produksi gabah organik memanfaatkan peluang pasar yang terbuka lebar. Konsekuensi dari tingginya permintaan tersebut adalah harga gabah organik yang dibeli dengan harga yang lebih tinggi dibandingkan gabah konvensional. Harga gabah organik dibeli dengan kisaran harga $5.000-5.500$ rupiah perkilogram, semenara itu gabah konvensional dibeli dengan kisaran 4.3004.700 rupiah per kilogram di tingkat petani.

Selain itu rendahnya biaya input produksi (pupuk dan pestisida) organik memperbesar nilai efisiensi usahatani. Pemanfaatan sumberdaya lokal seperti limbah peternakan dan sumberdaya biologis untuk pestisida alami sangat membantu efisiensi usahatani. Walaupun penggunaan tenaga kerja menjadi lebih besar, namun insentif harga cukup membantu mereka untuk meningkatkan pendapatan yang diterima tutur petani organik.

Pada aspek ekonomi ini, sistem kolektif yang dibangun dalam kelompok meningkatkan posisi tawar petani secara kelembagaan ekonomi. Akibatnya harga gabah yang diterima petani dapat lebih tinggi dibandingkan gabah konvensional. Kepercayaan Gapoktan melalui ICS juga secara ekonomi merupakan manfaat ekonomi yang berperan sebagai penjamin kepastian pasar. Tanpa kepercayaan dan posisi tawar yang baik, manfaat ekonomi yang diperoleh tidak akan optimal. Kepercayaan dan posisi tawar kelembagaan tidak muncul begitu saja apabila modal sosial yang ada pada kelompok tani tidak berkembang dengan baik.

c) Manfaat Lingkungan Pertanian Organik Dampak pada manajemen lahan adalah dampak yang siginifakan bagi lingkungan dalam pertanian organik (Morgera et al, 2012). Petani organik dengan bangga mnyampaikan bahwa kualitas lahan sawah yang mereka tanami telah kembali seperti pada masa mereka kecil, dimana tanah menjadi lebih remah dan tidak mudah kering pada saat musim kemarau.

Secara bilogis, keseimbangan ekosistem menjadi lebih terjaga. Fungsi konservasi lingkungan dalam bentuk kesejahteraan dan kesehatan hewan anggota ekosistem sawah yang sebelumnya terancam oleh keberadaan pestisida kimia saat ini telah berubah menjadi rumah bagi ekosistem sawah sebagaimana para petani seperti pada masa kanak-kanak di tahun 1970an.

Berdasarkan uraian di atas, modal sosial memiliki peranan yang penting dalam meningkatkan keberdayaan petani, dilihat dari aspek sosial, ekonomi dan lingkungan. Meminjam istilah Koutsou, et al (2014), "pohon" modal sosial yang tumbuh dengan baik pada kelompok tani Mekarjaya telah mampu menghasilkan "buah" kerjasama kolektif (collective action) dalam jumlah yang banyak dan kualitas yang baik. Sistem kolektif yang solid ini mempercepat peningkatan keberdayaan petani yang sebelumnya sangat bergantung kepada program pemerintah (subsidi pupuk) menjadi suatu kelompok yang lebih mandiri dalam menjalankan usahataninya.

\section{KESIMPULAN}

Sistem pertanian organik sebagai suatu inovasi cukup mampu meningkatkan keberdayaan ekonomi dilihat dari aspek sosial, ekonomi, dan lingkungan. Persoalan keberlanjutan (Kristiansen et al, 2006), pengikisan trnsfer teknologi (Mutmainah dan Sumardjo, 2014), kebergantungan (Tawaf et al, 2009) dan perusakan sosial dan lingkungan (Ife dan Tesoriero, 2008), walaupun tidak mutlak seluruhnya, tetapi sebagian besar dapat selesaikan dengan penerapan sistem pertanian organik yang holistik. Interaksi antara unsur usahatani padi, modal sosial, pengetahuan petani yang didukung eksternalitas usaha peternakan yang bekerja secara simultan sebagai sebuah sistem pertanian organik menghasilkan peningkatan keberdayaan petani 
skala kecil di Desa Sundakerta, Kec.

Sukahening Kab. Tasikmalaya.

Faktor penentu keberhasilan sistem pertanian organik adalah peran kelembagaan sosial yang diterjemahkan secara operasional menggunakan kosep modal sosial. Unsur kepercayaan, aturan dan norma, serta jejaring sosial saling berinteraksi dalam struktur modal sosial yang mengakselerasi peningkatan keberdayaan petani melalui suatu kerjasama kolektif (collective action) kelompok tani yang solid.

\section{UCAPAN TERIMA KASIH}

Apresiasi dan penghargaan kami sampaikan kepada Universitas Padjadjaran yang mendanai penelitian ini melalui skema Hibah Pengembangan Kapasitas Riset Dosen (HPKRD) tahun 2016. Apresiasi dan penghargaan juga kami sampaikan kepada Gapoktan Simpatik dan Kelompok Tani Mekarjaya yang telah bersedia menjadi wahana pembelajaran.

\section{DAFTAR PUSTAKA}

Alfiasari, M.D. and Dharmawan, A.H., 2009. Modal sosial dan ketahanan pangan rumah tangga miskin d kecamatan tanah sereal dan kecamatan bogor timur, kota bogor. Jurnal Sodality, 3(01).

Beban, A., 2008. Organic Agriculture: An Empowering Development Strategy for Small-Scale Farmers? A Cambodian Case Study. Unpublished master's thesis), Massey University, Palmerston North, NZ.

Coleman, J.S., 1988. Social capital in the creation of human capital. American journal of sociology, 94, pp.S95-S120.

Forrester, J.W., 1975. Collected papers of Jay W. Forrester.-.

Heryanto, M.A., Sukayat, Y. and Supyandi, D., 2016. Model Perilaku Petani dalam Adopsi Sistem Usahatani Padi Organik: Paradoks Sosial-Ekonomi-Lingkungan. Sosiohumaniora, 18(2).

Heryanto, M.A. and Supyandi, D., 2016. Model Peran Lembaga Riset dalam Sistem Inovasi Frugal sektor Pertanian: Pendekatan Analisis Berpikir Sistem. STI Policy and Management Journal, 10(2), pp.67-82.

Ife, J. and Tesoriero, F., 2008. Community Development: Alternatif Pengembangan Masyarakat di Era Globalisasi. Yogyakarta: Pustaka Pelajar.

Karaulova, M., Shackleton, O., Liu, W., Gök, A. and Shapira, P., 2016. Institutional change and innovation system transformation: A tale of two academies. Technological Forecasting and Social Change.

Koutsou, S., Partalidou, M. and Ragkos, A., 2014. Young farmers' social capital in Greece: Trust levels and collective actions. Journal of Rural Studies, 34, pp.204-211.

Kristiansen, P., Taji, A. and Reganold, J.P. eds., 2006. Organic agriculture: $a$ global perspective. CSIRO publishing.

Maxwell, J.A., 1996. Applied social research methods series, Vol. 41. Qualitative research design: An interactive approach. Thousand Oaks, CA: Sage Publications.

Morgera, E., Caro, B. and Durán, M., 2012. Organic agriculture and the law. FAO of the United Nations.

Mutmainah, R., 2015. Peran kepemimpinan kelompok tani dan efektivitas pemberdayaan petani. Sodality: Jurnal Sosiologi Pedesaan, 2(3).

Nasdian, F.T., 2014. Pengembangan masyarakat. Yayasan Pustaka Obor Indonesia.

Sadono, D., 2008. Pemberdayaan Petani: Paradigma Baru Penyuluhan Pertanian di Indonesia. Jurnal penyuluhan, 4(1).

Senge, P.M., 2006. The fifth discipline: The art and practice of the learning organization. Crown Pub.

Sumodiningrat G. 1999. Pemberdayaan Masyarakat dan Jaringan Pengamanan Sosial. Jakarta: PT Gramedia Pustaka Utama.

Sterman, J.D., 2000. Business dynamics: systems thinking and modeling for a complex world: Jeffrey J.

Tasrif, M., 2005. Analisis Kebijakan Menggunakan Model System Dynamics. Bandung: Program Magister Studi Pembangunan. Institut Teknologi Bandung.

Tawaf, R., Heriyadi, D., Anang, A., Sulaeman, M. and Hidayat, R., 2011. Empowerment of small holder farmers business Garut sheep in west java. Abstrak.

Tjitropranoto, P., 2005. Pemahaman Diri, Potensi/Kesiapan Diri, dan Pengenalan Inovasi. Jurnal Penyuluhan, 1(1).

Winter, I., 2000. Towards a theorised understanding of family life and social capital (p. 21). Melbourne: Australian Institute of Family Studies.

Zaini, Z., 2009. Memacu peningkatan produktivitas padi sawah melalui inovasi teknologi budi daya spesifik lokasi dalam era revolusi hijau lestari. Pengembangan Inovasi Pertanian, 2(1), pp.35-47. 